\title{
Research on the cooperated optimization model of energy in iron and steel enterprises
}

\author{
LI Bing ${ }^{1, a}$, NIU Hong-hai ${ }^{1, b}$, CHEN Jun ${ }^{1, c}$, PENG Xin ${ }^{1, d}$ \\ ${ }^{1}$ Research Department of Nari-Relays Electric Co., Ltd., Jiangsu, China \\ lab@nrec.com, ${ }^{\mathrm{b}}$ niuhh@nerc.com, ${ }^{\mathrm{c}}$ chenj@nerc.com , ${ }^{\mathrm{d}}$ pengx@nerc.com
}

Key words: iron and steel enterprises; energy system; cooperated optimization; energy-saving

\begin{abstract}
The cooperated optimization model of energy in iron and steel enterprises is built based on the research of coupling relationship of gas, steam and power. And by using the hierarchical decomposition method, the model is broken down into two parts: optimization of gas system and optimization of thermal and power system. The case analysis indicates that: the model can dispatch the energy of gas, steam and power reasonably, safely and efficiently when the production condition is changed, and improve the energy utilization efficiency.
\end{abstract}

\section{Introduction}

Iron and Steel Industry is an important basic industry of China and also a big energy consumer in manufacturing industry, which accounts for more than 15\% of China's energy consumption. High energy consumption has increasingly become an important problem restricting the development of Iron and Steel Industry. Iron and steel enterprises have many energy-saving measures, such as improving technological process, raising equipments' energy efficiency, optimizing energy dispatching method, etc.. Wherein, optimizing energy dispatching and raising energy utilization rate are easier to implement than other energy-saving measures, and have relatively big energy-saving space, so they are important breakthrough for Iron and steel enterprises' energy saving and consumption reduction.

In recent years, many scholars have carried out plentiful researches on iron and steel enterprises' energy optimization models. Documents [1-2] have established the models for predicting the supply and demand of byproduct gas, and on this basis, they have used mixed integer linear programming (MILP) for optimal dispatching of byproduct gas between gas holders and boilers of its self-supply power plant, realizing the safety control of gas holders and the maximum benefit of power generation. However, this type of model is mainly for the optimal dispatching of byproduct gas between buffer units, and does not involve the whole energy system. Documents [3-5] use linear programming method to research iron and steel enterprises' energy optimal dispatching, express the energy flowing between equipments and working procedures as a series of linear equations, and carry out optimal energy dispatching aiming at the minimum energy cost. However, such models do not consider the coupling relationship between byproduct gas, steam and electric power, etc., as well as the differences of equipments' energy efficiency when different energy resources are used.

Based on the above two models, this paper adopts system engineering method to research the coupling relationship of byproduct gas- steam - electric power, establishes the cooperated optimization model, disintegrates the model based on hierarchical theory, solves the sub models with linear programming method, and provides instructions for iron and steel enterprises' energy dispatching.

\section{Iron and steel enterprises' multi-energy cooperated optimization model}

The byproduct gas generated from coking, iron making, and steel making are supplied to gas users after pressurization, surplus gas is sent to power plants' boilers for power generation. The small quantity of gas imbalance frequently aroused by fluctuation of working condition is absorbed by gas cabinet, when surplus gas is insufficient, the boiler will be switched into the model of coal firing or gas coal co-firing. 
Generally, coke oven, heating furnace and boiler, etc. have fuel interchangeability, that's to say, if allowed technically, such devices may use different fuels; when different fuels are used, the devices have differences in fuel consumption of unit output. Therefore, reasonable gas proportioning may lower the energy consumption of the system; meanwhile, similar devices running in parallel have differences in conversion efficiency when manufacturing different energy resources, so iron and steel enterprises' multi-energy cooperated optimization may be disintegrated into the following problems:

(1) In the precondition of knowing enterprises' production plan and equipments maintenance plan, we may reasonably allocate various fuels (blast furnace gas, converter gas, coke oven gas, mixed gas, coal) to different energy consumption devices; in condition of meeting production demand, we shall minimize the loss of energies caused by the mixture of energy resources of different qualities, lower the energy diffusion of the system, and control the energy consumption of the whole enterprises' fuel system within the minimum scope;

(2) Buffer surplus gas between gas cabinet and power plant boiler reasonably, realize the optimum allocation of stem turbine's steam and electrical load according to the dynamic characteristics of steam turbine.

\subsection{Objective Function}

The objective function of steel and iron enterprises' multi-energy cooperated optimization model is as shown in Formula (1): the first item indicates the consumption cost of various energy resources; the second item indicates gas diffusion cost; the third item indicates power generation benefit; and the fourth item indicates power plant's ordinary heating benefit.

$$
\min S=\min \left(\sum_{i=1}^{m+n} \sum_{k=1}^{4} \psi_{k} X_{i, k}\right)+\min \sum_{k=1}^{3} \psi_{k} V_{\text {flare }, k}-\sum_{j=1}^{n} \psi_{5} P_{\text {power }-j}-\sum_{j=1}^{n} \psi_{6} D_{\text {steam }-j}
$$

Where $X_{i, k}$ The consumption of energy resource $\mathrm{k}$ of equipment $\mathrm{i}, \mathrm{m}^{3} / \mathrm{h}$ or $\mathrm{t} / \mathrm{h}, \mathrm{k}=1$ indicates blast furnace gas, $\mathrm{k}=2$ indicates converter gas, $\mathrm{k}=3$ indicates coke oven gas, $\mathrm{k}=4$ indicates coal, $\mathrm{k}=5$ indicates electric power, and $\mathrm{k}=6$ indicates steam; $\psi_{k}$ - The value coefficient of energy resource $\mathrm{k}$, $\mathrm{kJ} / \mathrm{kg}$ or $\mathrm{kJ} / \mathrm{m}^{3} ; V_{\text {flare }, \mathrm{k}}$ — The diffusion of energy resource $\mathrm{k}, \mathrm{m}^{3} / \mathrm{h} ; P_{\text {power }-j}$ - The power generation load of machine set j, MW; $Q_{\text {steam-j }}$ The ordinary heating load of machine set $\mathrm{j}, \mathrm{kJ} / \mathrm{h}$; $\mathrm{m}, \mathrm{n}$ - The main working procedure has m sets of equipment, and the power plant has $\mathrm{n}$ sets of machine.

\subsection{Restriction Conditions}

(1)Restriction on energy demand of the production unit i:

$$
\sum_{k=1}^{3} X_{i, k^{*}} \varphi_{k}=e_{i}^{*} p_{i}=f(\delta)^{*} p_{i}
$$

Where $p_{j} \longrightarrow$ The product output of the production unit $\mathrm{i}, \mathrm{t} / \mathrm{h} ; e_{i}-$ The fuel consumption per unit output of the production unit i, kJ/t; $\varphi_{k}$ — The standard coal coefficient of energy resource $\mathrm{k}, \mathrm{kJ} / \mathrm{kg}$ or $\mathrm{kJ} / \mathrm{m}^{3} ; \delta-$ The proportion of coke oven gas in mixed coal gas.

(2)Restriction on fuel's heat value of unit i:

$$
Q_{i_{-} \max } \geq Q_{i} \geq Q_{i_{-} \min }
$$


Over-low heat value of fuels will make it impossible to reach the required theoretical combustion temperature, while over-high heat value of fuels will be harmful to metal heating. The heat value of mixed fuels is calculated with the following formula:

$$
Q_{i}=\frac{\sum_{k=1}^{3} X_{i, k} * Q_{k}}{\sum_{k=1}^{3} X_{i, k}}
$$

Where $Q_{i} \longrightarrow$ The heat value of gas $\mathrm{k}, \mathrm{kJ} / \mathrm{m}^{3} ; Q_{i_{-} \max } \longrightarrow$ The maximum heat value that the production unit i can bear, $\mathrm{kJ} / \mathrm{m}^{3} ; Q_{i_{-} \min } \longrightarrow$ The minimum heat value that the production unit i can bear, $\mathrm{kJ} / \mathrm{m}^{3}$.

(3)Restriction on the proportioning of mixed gas (the proportion of coke oven gas in the mixed gas): The proportioning of coal gas supplied by the same pressurized station shall be the same and within the scope of technical requirements:

$$
\delta_{\min } \leq \frac{X_{i, 3}}{X_{i, 1}+X_{i, 2}+X_{i, 3}} \leq \delta_{\max }
$$

Where $\delta_{\min } \longrightarrow$ The minimum gas proportioning; $\delta_{\max } \longrightarrow$ The maximum gas proportioning (4)Restriction on safety of gas cabinet:

$$
0 \leq D_{k}-\sum_{i=1}^{m+n} X_{i, k}-V_{\text {flare }, \mathrm{k}} \leq V_{\max , k}
$$

Where $D_{k}-$ The output of coal gas $\mathrm{k}, \mathrm{m}^{3} / \mathrm{h} ; V_{\max , \mathrm{k}}$ The quantity of coal gas available to buffer in the gas cabinet $\mathrm{k}$ within the dispatching cycle, $\mathrm{m}^{3} / \mathrm{h}$.

(5)The maximum surplus gas absorbed by power plant boiler:

$$
\sum_{j=1}^{n} X_{j, k} \leq X_{k \max }
$$

Where $X_{k \max }$ The maximum of gas k that can be absorbed by power plant boiler, $\mathrm{m}^{3} / \mathrm{h}$. 
(6)Restriction on energy balance of power plant boiler j:

$$
\sum_{k=1}^{4} X_{\text {power- }-, k} * \psi_{k}^{*} \eta_{b, j}=\Delta H * D_{j}
$$

Where $\eta_{b, j} \longrightarrow$ The efficiency of boiler j, \%; $\Delta H-$ Per unit heat absorption of water supplied in the boiler, $\mathrm{kJ} / \mathrm{t} ; D_{j} \longrightarrow$ The load of boiler $\mathrm{j}$, t/h.

(7)Restriction on the maximum capacity of boiler $\mathrm{j}$ :

$$
D_{j} \leq D_{j \max }
$$

Where $D_{j \max }-$ The maximum capacity of boiler $\mathrm{j}$, t/h.

(8)Restriction on power production demand:

$$
\sum_{j=1}^{n} P_{e l, j} \geq P_{e l-d e m}
$$

Where $P_{e l_{-} \text {dem }} \longrightarrow$ Electrical load demand ,MW.

(9)Restriction on steam production demand:

$$
\sum_{j=1}^{n} D_{g r, j} \geq D_{g r_{-} d e m}
$$

Where $Q_{g r_{-} \text {dem }}-$ Heating load demand, $\mathrm{t} / \mathrm{h}$.

(10)Dynamic characteristics equations of the machine set $\mathrm{j}$ :

$$
\left\{\begin{array}{l}
D_{j}=k_{1, j} * P_{e l, j}+k_{2, j} * D_{g r, j} \\
D_{g r, j} \leq D_{g r, j \max } \\
P_{e l, j} \leq P_{e l, j \max }
\end{array}\right.
$$

Where $k_{1, j} 、 k_{2, j}$ - The dynamic characteristic coefficient of machine set $\mathrm{j} ; D_{g r, j \max }$ — The maximum heating load of machine set $\mathrm{j}, \mathrm{t} / \mathrm{h} ; P_{e l, j}-$ The maximum power generation load of machine set $\mathrm{j}$, MW. 
The parameters of the above restrictions are obtained by means of statistical analysis, regression analysis, modeling by mechanism, etc.

\section{Case Analysis}

Use the abovementioned model to carry out multi-energy cooperated optimization with a steel and iron factory as example. According to statistics, the steel factory's unit product output of blast furnace gas/ converter gas/ coke oven gas is $1620.5 \mathrm{~m}^{3} / \mathrm{t}$ molten iron $/ 67.7 \mathrm{~m}^{3} / \mathrm{t}$ steel $/ 410 \mathrm{~m}^{3} / \mathrm{t}$ coke, the steel factory has 8 gas pressurized stations in total, thermal power plant has 5 machine sets.

Use the model mentioned in Section 1 to optimize the following two production conditions:

Working condition 1: Normal production (as shown in the Table1); Working condition 2 (as shown in the Table2): Based on working condition 1, tubular production factory is stopped, the coking output is reduced by $30 \%$, the optimization results of gas system are as shown in Table1 and Table2, and those of thermal power production system are as shown in Table3.

Table1 The optimization results of gas system in working condition1

\begin{tabular}{|c|c|c|c|c|c|}
\hline Working procedure & $\begin{array}{c}\text { Pressurized } \\
\text { station }\end{array}$ & $\begin{array}{l}\text { Output } \\
(\mathrm{t} / \mathrm{h})\end{array}$ & $\begin{array}{c}\text { Blast furnace } \\
\text { gas } \\
\left(\mathrm{m}^{3} / \mathrm{h}\right)\end{array}$ & $\begin{array}{c}\text { Converter } \\
\text { gas } \\
\left(\mathrm{m}^{3} / \mathrm{h}\right)\end{array}$ & $\begin{array}{c}\text { Coke oven } \\
\text { gas } \\
\left(\mathrm{m}^{3} / \mathrm{h}\right)\end{array}$ \\
\hline Coking & $\# 1$ & 467 & 364432 & 0 & 40492 \\
\hline Sintering & $\# 2$ & 1188 & 7159 & 0 & 7159 \\
\hline Pelletizing & \#3 & 222 & 2271 & 0 & 9085 \\
\hline Iron making & $\# 4$ & 1389 & 979796 & 0 & 0 \\
\hline Steel making & & 1260 & זרינו & 0 & 10101 \\
\hline Continuous casting & \#5 & 1180 & 4025 & 0 & 16101 \\
\hline Thick plate & \#6 & 115 & 17871 & & 17071 \\
\hline Wire & \#O & 88 & $1 / 821$ & 0 & $1 / 821$ \\
\hline Tubular products & \multirow{4}{*}{ \#7 } & 53 & \multirow{4}{*}{30426} & \multirow{4}{*}{20284} & \multirow{4}{*}{50710} \\
\hline Medium board & & 98 & & & \\
\hline Thin board & & 672 & & & \\
\hline Section bar & & 71 & & & \\
\hline Power plant & $\# 8$ & & 843971 & 63971 & 50142 \\
\hline Diffusion & & & 0 & 0 & 0 \\
\hline
\end{tabular}


Table2 The optimization results of gas system in working condition2

\begin{tabular}{|c|c|c|c|c|c|}
\hline Working procedure & $\begin{array}{c}\text { Pressurized } \\
\text { station }\end{array}$ & $\begin{array}{c}\text { Output } \\
(\mathrm{t} / \mathrm{h})\end{array}$ & $\begin{array}{c}\text { Blast furnace } \\
\text { gas } \\
\left(\mathrm{m}^{3} / \mathrm{h}\right)\end{array}$ & $\begin{array}{c}\text { Converter } \\
\text { gas } \\
\left(\mathrm{m}^{3} / \mathrm{h}\right)\end{array}$ & $\begin{array}{c}\text { Coke oven } \\
\text { gas } \\
\left(\mathrm{m}^{3} / \mathrm{h}\right)\end{array}$ \\
\hline Coking & $\# 1$ & 327 & 255102 & 0 & 28345 \\
\hline Sintering & $\# 2$ & 1188 & 7159 & 0 & 7159 \\
\hline Pelletizing & $\# 3$ & 222 & 2271 & 0 & 9085 \\
\hline Iron making & $\# 4$ & 1389 & 979796 & 0 & 0 \\
\hline Steel making & \multirow{2}{*}{$\# 5$} & 1260 & \multirow{2}{*}{4025} & \multirow{2}{*}{0} & \multirow{2}{*}{16101} \\
\hline Continuous casting & & 1180 & & & \\
\hline Thick plate & \multirow{2}{*}{$\# 6$} & 115 & \multirow{2}{*}{17821} & \multirow{2}{*}{0} & \multirow{2}{*}{17821} \\
\hline Wire & & 88 & & & \\
\hline Tubular products & \multirow{4}{*}{ \#7 } & 0 & \multirow{4}{*}{27307} & \multirow{4}{*}{18205} & \multirow{4}{*}{45512} \\
\hline Medium board & & 98 & & & \\
\hline Thin board & & 672 & & & \\
\hline Section bar & & 71 & & & \\
\hline Power plant & $\# 8$ & & 956419 & 67050 & 10035 \\
\hline Diffusion & & & 0 & 0 & 0 \\
\hline
\end{tabular}

Table3 Comparison of the optimization results of thermal and power system in different conditions

\begin{tabular}{|c|c|c|c|c|}
\hline \multirow[b]{2}{*}{$\begin{array}{c}\text { Machine set } \\
\text { No. }\end{array}$} & \multicolumn{2}{|c|}{ Working condition 1} & \multicolumn{2}{|c|}{ Working condition 2} \\
\hline & $\begin{array}{c}\text { Power } \\
\text { generation } \\
\text { load (MW) }\end{array}$ & $\begin{array}{l}\text { Heating } \\
\operatorname{load}(\mathrm{t} / \mathrm{h})\end{array}$ & $\begin{array}{c}\text { Power } \\
\text { generation } \\
\text { load (MW) }\end{array}$ & $\begin{array}{l}\text { Heating } \\
\operatorname{load}(\mathrm{t} / \mathrm{h})\end{array}$ \\
\hline$\# 1$ & 30 & 88 & 30 & 88 \\
\hline$\# 2$ & 30 & 64 & 30 & 54 \\
\hline \#3 & 60 & 28 & 60 & 0 \\
\hline$\# 4$ & 60 & 57 & 50 & 68 \\
\hline$\# 5$ & 55 & 63 & 30 & 90 \\
\hline
\end{tabular}

Table 1-3 show that, after the change of production conditions, using multi-energy cooperated optimization model may re-allocate the energy resources without energy diffusion, and meanwhile, thermal power generation system is also optimized. 


\section{Conclusion}

This paper comprehensively considers the coupling relationship between the production and consumption of coal gas, steam, and electric power, establishes steel and iron enterprises' multi-energy cooperated optimization model, and then based on hierarchical theory, it splits the model into gas system and thermal power system for optimization respectively. Case study shows that, in condition of knowing production plan and maintenance plan, we may use the model to optimize and adjust energy production and distribution, avoid energy diffusion, and raise energy utilization rate.

\section{References}

[1] ZHANG qi, CAI Jiu-ju, PANG Xing-lu, et al. Optimal distribution of by-product gases in iron and steel complex [J]. Journal of Northeast University, 2011, 32(1): 98-101.

[2] ZHANG qi, CAI Jiu-ju, DU Tao. Optimum utilization of gas system in incorporated business enterprises of iron and steel [J]. Energy for Metallurgical Industry, 2005, 24(5): 9-16.

[3] Kim J H, Yi H S, Han C H. A novel model for plant-wide multi-period optimization of byproduct gas supply system in the iron and steel making process[J], Trans IChemE, 2003, 81: 1015-1025.

[4] Kim J H, Yi H S, Han C H. Plant-wide optimal byproduct gas distribution and holder level control in the iron and steel making process[J], Korean Journal of Chemical Engineering, 2003, 20(3): 429-435.

[5] W.R.Gray, J.D.Fekete, M.I.Tarkoff. A steel plant energy model [J], Iron and Steel Engineer, 1974, 11:54-59. 